Immigration and the Welfare State: The roles of employers and trade unions

2020 Special Issue for the Journal of European Social Policy

\title{
The roles of employers and trade unions in immigration and welfare state policy-making
}

December 15, 2020

Carlo Knotz, Flavia Fossati, Gemma Scalise and Gerda Hooijer

\begin{abstract}
Whether and under which conditions immigrants should be admitted and obtain access to employment and social security is an issue of continuously high political salience across the advanced democracies. Unions and employers, as traditionally influential actors in immigration and social policymaking, have important roles to play in this area, but their exact preferences, strategies and behaviour are theoretically difficult to determine and are still only partly understood. This article outlines a series of research problems that analyse the roles of social partners in the social and economic integration of immigrants and discusses how the articles contained in this special issue address these problems.
\end{abstract}

\section{Introduction}

The regulation of immigration and the integration of immigrants into host countries' economies and societies are among the top political challenges across the advanced democracies and beyond, and they have been for some time. Historical accounts of the Age of Migration to the United States in the late $19^{\text {th }}$ and early $20^{\text {th }}$ centuries, for instance, have documented the concerns among workers and trade unions about unfair competition; the concerns among many residents, including employers, about the strain put on public resources by the inflow of immigrants with modest means and needs for social support; and the cutbacks to redistributive arrangements that were frequently introduced in response to immigration (Heald, 1953; Tabellini, 2019). Any contemporary observer will surely agree that the situation has not been very different in recent years. 
A great deal of research has been concerned with the political tensions around immigration policy and the inclusion of immigrants into welfare states (Alesina and Glaeser, 2004; Cornelius and Rosenblum, 2005; Eger, 2010). However, thus far, much of this research has focused on the perceptions and actions of voters (e.g. Alesina and Glaeser, 2004; Eger, 2010; Ford, 2016) and the behaviour of political parties (Afonso and Rennwald, 2018; Careja et al., 2016; Ennser-Jedenastik, 2018; Fenger, 2018), finding persistent opposition among voters to the extension of social rights to immigrants and according responses among some political parties (see also Freeman, 1986; Kriesi et al., 2008).

The positions of employers and trade unions regarding the regulation of immigration and the apparent tension between immigration and social solidarity are less well understood. Of course, employers and unions have played a central role in research on welfare state development and reform (Korpi, 1983; Mares, 2003; Paster, 2013; Swenson, 1991), as well as in research on immigration policymaking in the political economy and industrial relations fields (Afonso, 2012; Caviedes, 2010; Haus, 1995, 1999; Marino et al., 2017; Menz, 2010; Penninx and Roosblad, 2002; Watts, 2002). However, there is less research that explains social partners' stances and actions across the two policy areas. ${ }^{1}$

This special issue contributes to filling this gap by exploring and casting new light on the roles of employers and trade unions in immigration and social policy-making, drawing on different theoretical and methodological approaches, including survey experiments at the level of individual voters or employers, in-depth analyses of local policy-implementation processes in European cities, and cross-country comparative analyses encompassing advanced democracies over multiple decades. In doing so, it also bridges the fields of welfare state, political economy, political sociology and industrial relations research.

In this introductory article, we set the stage for the various contributions to the special issue. More specifically, we first delineate the set of policies that this issue is concerned with, namely, immigration and social policies, which are also commonly referred to as the 'immigration-welfare nexus' (IWN). Following this, we develop a series of theoretical

\footnotetext{
${ }^{1}$ Penninx and Roosblad (2002) and Marino et al. (2017) are notable exceptions in that they also consider whether unions promote the inclusion of immigrants into social protection system, but they do not analyse the attitudes or behaviours of employers.
} 
questions about the interests and roles of these two actors at different stages of the policymaking process in the IWN and outline how the contributions to this special issue address these questions. We conclude and suggest avenues for further research in the final section of this article.

\section{The roles of unions and employers in the 'immigration-welfare nexus'}

This issue is concerned with immigration and social protection policies. Immigration policies are the rules that determine the entry of, the duration and conditions of stay and possibly the exit of immigrants from a given host country (e.g. Helbling et al., 2017) and that regulate not only the size of the immigrant population but also its composition, for instance, in terms of education, language skills, and reason for migration. Social protection policies include income support schemes and services for vulnerable populations but are often also defined more broadly to encompass labour market policies such as dismissal protection rules or minimum wages. We also adopt this broad definition. At the intersection of these two policy areas are the social rights of immigrants, or the rules that define directly or indirectly to what extent one's immigration status determines one's access to social protection policies (e.g. Careja et al., 2016). We subsume all these policies under the term IWN (building on Kulin et al., 2016).

When thinking about the roles of trade unions and employers in this IWN, one may intuitively think of their roles as interest groups in the political decision-making process. The two actors do certainly play significant roles in that process, and it is therefore an important aspect that several of the contributions to this special issue consider. However, employers and unions play important roles at other points of the policy cycle as well, i.e., as participants in public debates, in the implementation of immigration and social policies, and as recipients of policies, and they may shape policies' effects at these points of the cycle. In the following, we explain how the behaviour of either actor in these various arenas poses interesting theoretical challenges. 
Negotiation and policy-making in the immigration-welfare nexus

When it comes to the design of immigration policies and the social rights of immigrants, employers and trade unions are both strongly cross-pressured actors, and their behaviour is therefore difficult to predict. Employers' preference for open labour markets, for instance, is often more than counterbalanced by concerns about unfair competition (Afonso, 2012). And even if employers are in favour of free labour mobility, they may at the same time be hesitant to support the inclusion of immigrants into welfare arrangements where this inclusion creates additional costs (Heald, 1953); this is arguably especially so when the motivation to recruit from abroad reflects a (perceived) lacking flexibility and tractability of the domestic labour force (Caviedes, 2010).

Unions also face serious dilemmas in relation to immigration and immigrant workers (Penninx and Roosblad, 2002; Marino et al., 2015, 2017). They have an obvious economic interest in limiting the supply of labour to increase their prices and their members' wages, thereby giving them a reason to oppose any increases in labour supply due to immigration (Boräng and Cerna, 2019). At the same time, however, unions often also have long-standing ideological commitments to internationalism, equality, and worker solidarity that may make it difficult for them to justify tough immigration laws or the different treatment of immigrant workers. In addition, organizational interests may lead them to pursue more inclusive strategies such as championing immigrants' economic and social rights to prevent immigrants from undercutting existing regulatory standards and to attract immigrant workers as potential new members (see in particular Haus 1995; Watts 2002).

Two contributions to this issue provide new evidence on the role and interests of trade unions. The contribution by Boräng, Kalm and Lindvall provides a long-term perspective on the role of trade unions for both immigration policy and the social rights of immigrants. They show that the organizational strength of trade unions matters and that union strength has been related to immigrant policy in different ways over the long time period studied. Using historical data on union density and social and economic rights for migrants, the authors show that union 
strength, at first, results in a widening rights gap between immigrants and citizens, likely because the rights of citizens expanded sooner and more quickly than the rights of immigrants. Over time, however, the differences between countries with strong and weak unions have diminished, and in more recent years, the "rights gap" between citizens and immigrants has in fact been smaller in countries with strong unions than in countries with weak unions.

The contribution by Afonso, Negash and Wolff complements the study by Boräng et al. in that it analyses more closely which conditions make it more likely for unions to pursue a strategy of either closure, equalization or organization with regard to immigrant workers in Great Britain, Sweden and Germany. The authors argue that the determinants for the choice of one or the other strategy lie mainly in trade unions' power resources. Their main finding is that strong unions (Sweden) resort to the best available solution and protect domestic and immigrant workers through collective bargaining. Unions with intermediate power (Germany) seek to find a balance between the equalizing and closure strategies by first restricting access and then focusing on the adoption of a minimum wage. Finally, unions with weak power (Great Britain) either cannot or do not influence legislation, instead opting for the organization of immigrant workers as a "weapon of the weak".

Public debate and agenda setting: are unions and employers effective public opinion influencers?

Unions and employers may also seek to influence policy-making by using their public profiles and organizational and financial resources to try to shape the public debate around immigration and the integration of immigrants (on the potential influence of elite communication on voter attitudes see e.g. Marx and Schumacher, 2016; Lupia, 1994).

Whether unions and employers can succeed in this is not obvious, however. First, an actor's success in opinion framing depends on the extent to which they are seen as credible (Druckman, 2001), and it is not clear that either actor is in fact deemed credible by voters. In 
particular, trade unions have been considered increasingly lacking in credibility in the eyes of the public (Culpepper and Regan, 2014). In the case of employers, at least some voters might suspect them to hold interests that differ from their own, which would in turn limit the influence of employers over these voters' attitudes. Hence, the overall question focuses on what degree of influence unions and employers have in the public discussion around the IWN.

The contribution by Donnelly, Islam, and Savoie answers this question. The authors' findings from survey experiments in Canada, Germany, and the United Kingdom suggest that unions and employers are quite constrained in their abilities to convince voters of their positions in the area of immigration policy and that either actor can only communicate effectively with particular subgroups of voters. These different effects may reflect variation in the perceived credibility of the two actors in the eyes of the different groups of voters. Overall, the findings by Donnelly et al. suggest that unions and employers do not really influence but may instead themselves be influenced and constrained by how the general public thinks about immigration.

Policy implementation and delivery: are social partners integration-enhancing or integratinghindering actors?

Employers and unions also play important roles outside the pure politics realm by influencing the implementation and effectiveness of policies that regulate the entry and socio-economic integration of immigrants. Employers may, for instance, be involuntarily tasked with immigration policy enforcement, as in the case of sanctions against employers that hire undocumented immigrants (Cornelius, 2005). How and to what extent do these actors participate faithfully in policy enforcement, given their often countervailing motives? Two contributions in this special issue highlight how country-specific traditions of industrial relations influence the degree of involvement of social partners in the implementation of labour market integration policies and immigration governance.

Kimberly Morgan's article offers an original perspective on cross-national differences in social partners' actions in the implementation phase regarding immigration policies. Focusing on employer sanctions, the article illustrates the key role played by the system of interest 
mediation for the behaviour of unions and employers. Morgan argues that in countries with institutionalized relationships between the social partners and the state, this coordination extends to the implementation of sanctions by employers. By contrast, in systems with less institutionalized cooperation, employers and unions are less likely to assist the immigration control objectives of state officials and may even actively resist these objectives.

While Morgan puts her focus on patterns at the national level, the contribution by Scalise and Burroni highlights the fact that much of the implementation of policies that regulate immigrants' integration happens at the local level. By focusing on local regulation, the authors show, on the one hand, the proactive stance of cities in delivering their own policies for immigrants and, on the other hand, the increasing relevance of local social partners in their development and implementation. The article distinguishes different types of urban-based labour mobilizations and diverse roles adopted by local unions and employers' organizations in the local policy cycle, from public campaigners and mobilizers to service providers and policy negotiation. On the basis of comparative research based on three cities in Sweden, Spain and France, the analysis of local immigration governance highlights bilateral and trilateral initiatives between industrial relations actors and local government and institutions, which cover various areas, including the labour market, integration, training, and humanitarian and asylum rights recognition.

The social partners also influence the efficiency and efficacy of labour market integration policies for immigrants in their roles as policy recipients. This is particularly evident in the case of employers, whose hiring behaviour is directly or indirectly targeted by labour market integration policies for immigrants. How they respond to such policies determines a great deal of their effectiveness and, in turn, immigrants' labour market outcomes. The contribution by Fossati and Liechti shows that employers can make a difference, particularly with respect to how active labour market programmes (ALMPs) affect immigrants' labour market integration. By means of a survey experiment, they show that whether employers consider ALMPs as valuable instruments to foster labour market integration of refugees depends on the attitudes they hold towards this group of immigrants in the first place. When employers believe that immigrants cannot make a meaningful contribution to the host society's labour market, they 
also do not consider ALMP participation when hiring, meaning that these measures remain ineffective. ALMPs unfold their positive integrating effect only when employers hold positive attitudes towards immigrants. Fossati and Liechti's contribution demonstrates that the successful implementation of welfare policies crucially depends upon employers' support for immigration and integration measures.

The last contribution to the special issue is a thematic review by Giuliano Bonoli, in which he discusses more generally to what extent the effectiveness of social investment policies in multicultural societies depends on employers' preferences and behaviour. He argues that in most countries, social investment policies have difficulties reaching the most disadvantaged individuals, particularly immigrants, and do not significantly reduce the labour market (access) hurdles experienced by these individuals. A key obstacle here remains discrimination by employers. Bonoli concludes that the role of employers ought to be considered more systematically in the design of social investment policies.

\section{Conclusion}

With this special issue, we shed light on the roles of two traditionally important political actors, namely, trade unions and employers, in the regulation of immigration and immigrants' social and economic integration across several relevant political arenas. The contributions featured in this issue show that and how either actor matters from the stage of policy formulation and negotiation over the public arena to their implementation and effectiveness in practice and thus contributes to filling a gap in existing research.

There are, of course, questions that remain open. For one, while several contributions to this issue have examined the roles of unions in the determination of immigration policies and the social rights of immigrants, more research is needed to explore the roles of employers in these policies, in particular for the latter. Employers' skill needs in interaction with domestic educational and training policies have showed to be important to explain employers' stances towards immigration policies (e.g. Menz, 2010, 2011), and they may also increase our understanding of employers' stances towards the social rights of immigrants. Second, more could still be done to improve our understanding of the direct strategic interaction of unions 
and employers in this setting. Third, we point out that the interactions between the social partners and international organizations such as the EU and the extent to which international policy-making enables or constrains unions and employers in the IWN deserve closer scrutiny than we have provided here (see e.g. Lindstrom, 2010).

Immigration has been a salient political issue for decades now, through severe economic crises in the past, such as the Great Depression and the global financial crisis, as well as the current public health and economic crisis due the COVID-19 virus (e.g. Piccoli, 2020). In this new and unexpected world, there will also be new theoretical questions to answer. These questions include, for instance, the following: will immigration policies ever return to being as liberal as in the world before the crisis, or will some of the measures taken to stop the diffusion of the virus become institutionalized (Hacker et al., 2015)? What role will employers be able to play in pressuring governments to re-open the borders to cover their need for (cheap) labour? Will employers be able to influence public opinion and support immigration rather than surrender to a protectionist economic and immigration policy strategy? Will unions be able to balance the demands of domestic workers without compromising their humanitarian principles and fight to retain the necessary social rights to ensure the successful socio-economic integration of immigrant workers? These topics will remain important in the years to come.

\section{References}

Afonso A (2012) Employer strategies, cross-class coalitions and the free movement of labour in the enlarged European Union. Socio-Economic Review 10(4): 705-730.

Afonso A and Rennwald L (2018) Social class and the changing welfare state agenda of radical right parties in Europe. In: Manow $\mathrm{P}$, Palier $\mathrm{B}$, and Schwander $\mathrm{H}$ (eds) Welfare Democracies and Party Politics: Explaining Electoral Dynamics in Times of Changing Welfare Capitalism. Oxford: Oxford University Press, pp. 171-194.

Alesina A and Glaeser E (2004) Fighting Poverty in the US and Europe: A World of Difference. Oxford: Oxford University Press.

Boräng F and Cerna L (2019) Constrained Politics: Labour Market Actors, Political Parties and Swedish Labour Immigration Policy. Government and Opposition 54(1). Cambridge University Press: 121-144. 
Careja R, Elmelund-Præstekær C, Klitgaard MB, et al. (2016) Direct and Indirect Welfare Chauvinism as Party Strategies: An Analysis of the Danish People's Party. Scandinavian Political Studies 39(4): 435-457.

Caviedes AA (2010) Prying Open Fortress Europe: The Turn to Sectoral Labor Migration. Rowman \& Littlefield.

Cornelius WA (2005) Controlling 'Unwanted' Immigration: Lessons from the United States, 1993-2004. Journal of Ethnic and Migration Studies 31(4): 775-794.

Cornelius WA and Rosenblum MR (2005) Immigration and Politics. Annual Review of Political Science 8: 99-119.

Culpepper PD and Regan A (2014) Why don't governments need trade unions anymore? The death of social pacts in Ireland and Italy. Socio-Economic Review 14(4): 723-45.

Druckman JN (2001) On the Limits of Framing Effects: Who Can Frame? Journal of Politics 63(4): 1041-1066.

Eger MA (2010) Even in Sweden: The Effect of Immigration on Support for Welfare State Spending. European Sociological Review 26(2): 203-217.

Ennser-Jedenastik L (2018) Welfare Chauvinism in Populist Radical Right Platforms: The Role of Redistributive Justice Principles: Welfare Chauvinism in Populist Radical Right Platforms: The Role of Redistributive Justice Principles. Social Policy \& Administration 52(1): 293-314.

Fenger M (2018) The social policy agendas of populist radical right parties in comparative perspective. Journal of International and Comparative Social Policy 34(3): 188-209.

Ford R (2016) Who Should We Help? An Experimental Test of Discrimination in the British Welfare State. Political Studies 64(3): 630-650.

Freeman GP (1986) Migration and the Political Economy of the Welfare State. Annals of the American Academy of Political and Social Science 485(1): 51-63.

Hacker JS, Pierson P and Thelen K (2015) Drift and conversion: Hidden faces of institutional change. In: Mahoney J and Thelen K (eds) Advances in Comparative-Historical Analysis. Cambridge: Cambridge University Press, pp. 180-208.

Haus L (1995) Openings in the Wall: Transnational Migrants, Labor Unions, and U.S. Immigration Policy. International Organization 49(2): 285-313.

Haus L (1999) Labor Unions and Immigration Policy in France. International Migration Review 33(3): 683-716.

Heald M (1953) Business Attitudes Toward European Immigration, 1880-1900. The Journal of Economic History 13(3): 291-304. 
Helbling M, Bjerre L, Römer F, et al. (2017) Measuring immigration policies: the IMPIC database. European Political Science 16(1): 79-98.

Korpi W (1983) The Democratic Class Struggle. Routledge.

Kriesi H, Grande E, Lachat R, et al. (2008) West European Politics in the Age of Globalization. Cambridge: Cambridge University Press.

Kulin J, Eger MA and Hjerm M (2016) Immigration or Welfare? The Progressive's Dilemma Revisited. Socius 2.

Lindstrom N (2010) Service Liberalization in the Enlarged EU: A Race to the Bottom or the Emergence of Transnational Political Conflict? JCMS: Journal of Common Market Studies 48(5): 1307-1327.

Lupia A (1994) Shortcuts Versus Encyclopedias: Information and Voting Behavior in California Insurance Reform Elections. American Political Science Review 88(1): 63-76.

Mares I (2003) The Politics of Social Risk: Business and Welfare State Development. Cambridge University Press.

Marino S, Penninx R and Roosblad J (2015) Trade unions, immigration and immigrants in Europe revisited: Unions' attitudes and actions under new conditions. Comparative Migration Studies 3(1): 1.

Marino S, Roosblad J and Penninx R (eds) (2017) Trade Unions and Migrant Workers: New Contexts and Challenges in Europe. Cheltenham, Northampton, MA \& Geneva: Edward Elgar \& ILO.

Marx P and Schumacher G (2016) The effect of economic change and elite framing on support for welfare state retrenchment: A survey experiment. Journal of European Social Policy 26(1): 20-31.

Menz G (2010) Employers, Trade Unions, Varieties of Capitalism, and Labour Migration Policies. In: Menz G and Caviedes A (eds) Labour Migration in Europe. Migration, Minorities and Citizenship. London: Palgrave Macmillan UK, pp. 25-53.

Menz G (2011) Employer Preferences for Labour Migration: Exploring 'Varieties of Capitalism'-Based Contextual Conditionality in Germany and the United Kingdom. The British Journal of Politics and International Relations 13(4): 534-550.

Paster T (2013) Business and Welfare State Development: Why Did Employers Accept Social Reforms? World Politics 65(3): 416-51.

Penninx R and Roosblad J (eds) (2002) Trade Unions, Immigration, and Immigrants in Europe, 1960-1993: A Comparative Study of the Attitudes and Actions of Trade Unions in Seven West European Countries. New York \& Oxford: Berghahn Books.

Piccoli L (2020) Coronavirus restrictions on movement may jeopardize the lives of the most vulnerable. Washington Post, 5 April. Washington D.C. Available at: 
https://www.washingtonpost.com/politics/2020/04/05/coronavirus-restrictionsmovement-may-jeopardize-lives-most-vulnerable/ (accessed 25 May 2020).

Swenson P (1991) Labor and the Limits of the Welfare State: The Politics of Intraclass Conflict and Cross-Class Alliances in Sweden and West Germany. Comparative Politics 23(4): 379-399.

Tabellini M (2019) Gifts of the immigrants, woes of the natives: Lessons from the age of mass migration. Harvard Business School Working Paper 19-005.

Watts JR (2002) Immigration Policy and the Challenge of Globalization: Unions and Employers in Unlikely Alliance. Ithaca und London: Cornell University Press. 